FILOLOGÍA HISPÁNICA 



\title{
LAS REFLEXIONES DE SARMIENTO A LAS ETIMOLOGÍAS DEL DICCIONARIO DE AUTORIDADES
}

\author{
ENRIQUE JiMÉnEZ Ríos \\ Universidad de Salamanca \\ enrique@usal.es
}

\section{RESUMEN}

El artículo examina las reflexiones que el padre Martín Sarmiento (1695-1772) hizo a las etimologías del primer diccionario de la Real Academia Española, el Diccionario de Autoridades. Para ello se contrasta su idea de la etimología con la de la corporación académica, expuesta en su Discurso proemial sobre las etimologías, y con la de otros autores del siglo XVIII, como Gregorio Mayans en sus Orígenes de la lengua castella$n a$. El resultado es la novedad del pensamiento etimológico del benedictino al otorgar más importancia al significante que al significado en la búsqueda del étimo de una voz y explicar el cambio formal no como una mera transformación de letras, sino como efecto de la actuación de los órganos de la articulación.

Palabras clave: Sarmiento, Etimología, Real Academia Española, Diccionario.

\section{AbStract}

In this article we examine the reflections made by Father Martín Sarmiento (1695-1772) concerning the etymologies in first dictionary published by the Spanish Royal Academy, the Diccionario de Autoridades. In doing so we compare his idea of etymology with that of the Academy, as posited in its Discurso proemial sobre las etimologías, and with that of other eighteenth century authors, such as Gregorio Mayans in his Orígenes de la lengua castellana. What we find is the originality of the etymological 
thought of the Benedictine father when he affords more importance to the signifier than the signified in the search for the etymon of a word and explains formal changes not as mere transformations of letters, but as the effect of the action of the organs of articulation.

\section{KeY words: Sarmiento, Etymology, Spanish Royal Academy, Dictionary.}

1. En el tomo 15 del Boletín de la Real Academia Española, correspondiente a 1928, aparecen publicadas las reflexiones que el padre Martín Sarmiento ${ }^{1}$ hizo sobre el Diccionario de Autoridades ${ }^{2}$. La Academia, con el deseo de dar a conocer, a través de su boletín, algunos de sus escritos relacionados con la lengua española y con la filología, publica los comentarios que el erudito berciano hizo a propósito de las etimologías. Constituyen un documento de gran valor lingüístico y lexicográfico: lingüístico, porque los trabajos de Sarmiento siempre tendrán un interés histórico apreciable, a pesar del paso del tiempo y de la evolución experimentada por los estudios filológicos; lexicográfico, porque si tenemos en cuenta que Sarmiento conoce las etimologías de la Academia de la misma manera que las de otros autores como Du Cange, Menage, Covarrubias o Bluteau $^{3}$, de las cuales dice que las deja atrás porque no ha tomado «la pluma para copiar sino para discurrir a mi modo» ${ }^{4}$, mucho le debieron de llamar la atención las de la

${ }^{1}$ Fray Martín Sarmiento (1695-1772), erudito español y escritor de saber enciclopédico, a él se deben los primeros estudios lexicográficos sobre el gallego. Destacan su Catálogo de voces vulgares y en especial de voces gallegas de diferentes vegetables y el Catálogo de voces y frases de la lengua gallega, de mediados del siglo XVIII. Pero ante todo Sarmiento es un etimólogo, y fruto de ese trabajo son las Conjeturas para establecer algunas etimologías de diferentes voces, que se usan en España, iniciadas en 1730; en 1756 escribe el Onomástico latín-gallego de los vegetables que vio el P. Sarmiento, seguido de Borrón de varios nombres gallegos de vegetables y el Onomástico etimológico de la lengua gallega, iniciado en 1757 y terminado en 1762. A esta serie de obras lexicológicas se unen los Elementos etimológicos según el método de Euclides, iniciado en 1758 y terminado en 1766, y el Discurso apologético por el arte de rastrear las más oportunas etimologías de las voces vulgares de 1770 . El punto de partida de estas dos obras son los Apuntamientos para un discurso apologético sobre las etimologías, escritos con anterioridad a los Elementos etimológicos.

${ }_{2}^{2}$ Se trata de la primera entrega de los escritos de Sarmiento que Julián Paz publicó en el boletín dentro de la serie Escritos filológicos, y que fueron apareciendo fragmentariamente desde el tomo XV de 1928 hasta el XVIII de 1931. Las páginas 446-457 del volumen XV contienen un Dictamen sobre una oración de Don Tomás Fernández de Mesa en alabanza de la lengua española; las páginas 670-684 de este mismo número y las páginas 244-255, 366-382 del volumen XVI de 1929, las páginas 275-290, 571-592, 721-742 del volumen XVII de 1930 y las páginas 118-135 del volumen XVIII de 1931 contienen los Elementos etimológicos según el método de Euclides. No son, por tanto, estas Reflexiones críticas al Diccionario de Autoridades las 16 últimas hojas de los Elementos etimológicos, como afirma el Conde de La Viñaza en su Biblioteca histórica (tomo III, col. 1514). Al contrario, en esta serie aparecen publicados en primer lugar.

Vid. también para el origen de esta obra el Estudio preliminar de los Elementos etimológicos de la edición de J. L. Pensado, p. 15.

${ }^{3}$ De todos esos autores y obras el antecedente principal y más estimado para Sarmiento es Menage con Le origini della Lingua Italiana (Ginebra, 1685) y, sobre todo, con el Dictionnaire Etymologique ou Origines de la Langue Française en la nueva edición con adiciones de Mr. de Casenueve, del P. Bessnier y de Abbé Chastelain (París, 1694). Esta edición del Dictionnaire estaba enriquecida con un «Discours sur la Science des Etymologies» por el P. Bessnier seguido de unos «Principes de l'Art des Etymologies ou Exemples de la diverse alteration des lettres», textos que pudieron haber servido de modelo para la redacción del Discurso proemial sobre las etymologias que la Academia española publica en las primeras páginas de su Diccionario de Autoridades.

${ }_{4}$ «Dejo atrás etimologías que alguno pudiera proponer en virtud de lo que leyese (y leí también) en los Glosarios de Du Cange, Skinner, Schilter; en los etimológicos de Vossio, Martinio y Covarrubias; en los Origines de la Lengua Francesa y Italiana de Mr. Menage, y en el Vocabulario del padre Bluteau y de la Academia 
corporación académica, ya que de manera detenida solo se ocupa de ellas ${ }^{5}$, y estamos ante una de las primeras críticas hechas al primer diccionario académico en un asunto por el que la Academia ha tenido una gran preocupación a lo largo de su historia, pues, desde los trabajos preparatorios del Diccionario de Autoridades hasta la última edición, la etimología ha sido objeto de atención, como se observa en las páginas preliminares de sus diccionarios 6 .

2. En el prólogo del primer diccionario académico, inmediatamente después de mostrar la necesidad de que el español cuente con un diccionario de la lengua, de la importancia de las autoridades y de su elección, así como del objetivo que persigue con la elaboración de este diccionario ${ }^{7}$, expone la Academia, por su ligazón con estos hechos, la postura adoptada para el tratamiento de las etimologías:

Por lo que mira a las Etymologías hace la Academia la misma ingenua expresión [que en ortografía] como se reconocerá por el discurso de ellas, que en adelante se pone. Habla la Academia de las Etymologías con el pulso y moderación que corresponde al peligro de errar: y tiene por más congruente evitar muchas, antes que exponerse a un error cierto, que justamente se le impugnasse (Prólogo, p. V).

Pulso y moderación resumen la postura con que la Academia se enfrenta a la etimología y expresan asimismo la dificultad para establecerla ${ }^{8}$ : el antecedente de Covarrubias, de quien disiente y a quien no pretende seguir -aunque se reconoce su labor ${ }^{9}-$, y la necesidad de fijar una norma ortográfica apoyada en el criterio etimológico, explican esta

Real de la Lengua Castellana, y en el de la Crusca de la última edición» (Vid. la Colección de Voces y frases gallegas. Edición y estudio por J. L. Pensado, Salamanca, Universidad de Salamanca, 1970, p. 210).

${ }_{5}$ Hay en su obra alguna crítica aislada a estos autores, como la que hace a Bluteau, de quien dice que «no se hallan en 10 volúmenes 6 etimologías que sean pasaderas» (Elementos etimológicos, § 203, p. 145). De Covarrubias dice: «No ha tenido, pues, razón Dn. Francisco de Quevedo, en la precipitada censura que dio del dicho Thesoro, que salió a luz el año de 1610, pues hasta el año 1726, en que salió el tomo $1 .^{\circ}$ del Diccionario de la Lengua Castellana de la Real Academia Española no había libro de forma ni de sustancia, para instruirse de el origen de las voces castellanas, a fundamentis. Es verdad que Covarrubias pone algunas etimologías poco acertadas. Pero eso es común a todo libro corpulento de etimologías. En 150 años han tenido los que censuran aquella obra, para corregirla, rectificarla, enmendarla y añadirla. El hecho es que los extranjeros citan y aprecian a Covarrubias» (Elementos etimológicos, $\S 206$, p. 145).

${ }^{6}$ La importancia del pensamiento etimológico de Sarmiento se refleja, además, en el aprovechamiento que de sus ideas hacen J. Corominas y J. A. Pascual en su Diccionario crítico etimológico castellano e hispánico (Madrid, Gredos, 1980-1991, 6 vols.), como pone de manifiesto Cotelo García (2010, pp. 74-86).

7 Una de las diferencias que encuentra la Academia entre diccionario y vocabulario reside en el tipo de información que se recoge: «porque en la Lengua Española se entienden comúnmente por Vocabularios los libros en que se expresan las voces, sin explicarlas, ni adornarlas con etymologias y phrases que se vuelven en otra Lengua» (Prólogo, p. II).

${ }^{8}$ Para el tratamiento, importancia y significado de la etimología en el siglo XVIII, y en particular, en el Diccionario de la Real Academia Española, vid. Jiménez Ríos (2003) y Jiménez Ríos (2008).

${ }^{9}$ En el prólogo del Diccionario de Autoridades se lee: «Es evidente que a este Autor se le debe la gloria de haver dado principio a obra tan grande, que ha servido a la Academia de clara luz en la confusa obscuridad de empressa tan insigne; [...] pero la Real Academia, venerando el noble pensamiento de Covarrubias, y siguiéndole en las voces en que halló proporción y verisimilitud, ha formado el Diccionario, [...] sin detenerse con demasiada reflexión en el origen y derivación de las voces: porque además de ser trabajo de poco fruto, sería penoso y desagradable a los lectores, que regularmente buscan la propiedad del significado: y el origen o la derivación, quando no es mui evidente y claro, quedaba siempre sujeto a varios conceptos, después de ser desapacible su lección, y que ocasionaría un volumen fastidioso y dilatado» (Prólogo, pp. I-II). El valor etimológico del Tesoro de Covarrubias ha sido destacado por Gutiérrez Cuadrado y Vidal Díez (2011), que ven en el enciclopedismo de la obra la manera para que el autor ofrezca sus interpretaciones etimológicas. 
actitud ${ }^{10}$. Pero también cabe apuntar como razón para esa consideración la falta de un método etimológico científico para cumplir adecuadamente con el objetivo que persigue la etimología ${ }^{11}$.

El interés en la etimología, como vía, además, para mostrar la pureza y la elegancia de la lengua castellana por su filiación al latín, es tan grande que no basta con hacer esta llamada de atención, sino que la Academia dedica un Discurso proemial sobre las etymologías a exponer detalladamente su concepción, objetivo y método con que debe ser tratada $^{12}$. En él presenta el sentido de la etimología, en lo que puede verse que la corporación académica sigue las ideas de la tradición grecolatina ${ }^{13}$, al tiempo que admite, como San Isidoro $^{14}$, que la relación que se establece entre una palabra y su referente no siempre es natural, sino que muchas veces es arbitraria y convencional; pero se trata de una convencionalidad guiada por las características de la cosa que tiene que ser nombrada:

La Etimología de una Voz es el origen, o principio que tuvo para su formación, o significado: y assi el estudio de las Etymologías es procurar saber y descubrir el verdadero origen, o principio de cada voz: pues si bien estas se definen rigurosamente, que son significativas al arbitrio y común consentimiento de los hombres, a estos los debemos suponer racionales, y que al tiempo de formar las Voces, mas se movieron por razón, que por capricho: y el fundamento de esta razón es lo que se llama Etymología, por ser la raíz y principio que tuvo la Voz o que tuvo su significación (Discurso proemial, pp. XLVIII) $)^{15}$.

${ }^{10}$ Inmediatamente antes del párrafo citado sobre la etimología habla la Academia de la ortografía. Y dice: «es mui grande el descuido o ignorancia que se padece en la Orthographia, aunque en ninguna Lengua habrá más tratados de esta esencial parte de explicar por escrito el Idioma, porque passan de treinta Autores los que han escrito sobre la Ortographía Castellana. La Academia no se ha introducido a impugnar, ni calificar a ninguno, y para su proprio uso ha establecido, y fijado su Orthographia, porque su intención no es enseñar, sino proceder por sí, constante en el modo de escribir, siguiendo para este fin las reglas que le han parecido más proporcionadas de los mismos Autores que han escrito de este asunto: como se comprueba por el tratado de Ortographía que sigue a este Prólogo: en cuya inteligencia se podrá seguir el método que pareciere conveniente, pues en tanta confusa variedad no podrá faltar comprobación» (Prólogo, pp. IV-V).

${ }^{11}$ Una exposición detallada del desarrollo experimentado por la etimología como ciencia a lo largo del siglo XIX a partir del nacimiento de la lingüística histórica y comparativa se hace en Malkiel (1996).

${ }^{12}$ En el Discurso proemial se expone, a propósito del ejercicio etimológico, que «este estudio es honesto, y aunque solo tuviera de honestidad evitar el ocio en quien se fatiga, tenía sobrado motivo para su alabanza. Este estudio es útil por el intento de descubrir y apurar la verdad. Este estudio es deleitable, no solo por aquel gusto y satisfacción que logra quien aplicado a cualquier Ciencia averigua una verdad, como aun particularmente por el recreo de conseguir que él proprio en su modo de hablar, y la Patria en el común y ordinario lenguage, logren entre naturales y forasteros el aplauso de puros, castizos y expresivos en sus Voces y Phrases» (Discurso proemial, pp. L).

${ }_{13}$ Por ejemplo, en el Cratilo de Platón se discute sobre si los nombres son por naturaleza o por convención. Para el personaje que da título al diálogo «existe naturalmente una denominación precisa para cada uno de los seres; es decir, que los nombres no son la denominación que suele darse a los objetos como consecuencia de un acuerdo o inteligencia previa en virtud del cual se les designa mediante una parte del lenguaje, sino que existe con existencia natural y propia una manera fija y precisa de denominar» (Platón, Cratilo o Del lenguaje. Traducción, notas e introducción de Vicente Bécares Botas, Salamanca, Ediciones Universidad de Salamanca, 1982, p. 1).

${ }^{14}$ Isidoro de Sevilla, Etimologías. Edición bilingüe de José Oroz Reta y Manuel A. Marcos Casquero. Introducción general por Manuel C. Díaz y Díaz. Madrid, BAC, 1983, 2 vols. 2. a edición.

15 En sus Etimologías San Isidoro define el término del siguiente modo: «La etimología estudia el origen de los vocablos, ya que mediante su interpretación se llega a conocer el sentido de las palabras y los nombres. Aristóteles la denominó symbolon, y Cicerón, adnotatio, porque, a partir de un modelo, se nos dan a conocer las palabras y los nombres de las cosas. Por ejemplo, flumen (río) deriva de fluere, porque fluyendo crece. Su conocimiento implica a menudo una utilización necesaria en la interpretación léxica. Pues, si se sabe cuál es el origen de una palabra, más rápidamente se comprenderá su sentido. El examen de cualquier objeto es mucho 
Para la Academia, determinar el origen y el significado primero -o primitivo- de una palabra resultaba una tarea difícil, y lo era por dos motivos: primero, por un motivo lingüístico, dada la cantidad de datos de que se necesita disponer; y segundo, por un motivo extralingüístico, dado el ambiente adverso a la etimología que había en el momento en que nació la corporación y que hacía de la búsqueda etimológica una actividad más ligada a la adivinación que al ejercicio científico; de hecho, la etimología ejercida durante el siglo XVII había hecho de esta actividad una práctica en la que todo era lícito en la pesquisa etimológica ${ }^{16}$. Esta situación explica la adversidad a que se enfrentaba el estudio de las etimologías en el siglo XVIII ${ }^{17}$.

3. Para luchar contra ello, como método de estudio y análisis, la Academia ofrece en ese discurso proemial diez reglas ${ }^{18}$ para determinar adecuadamente la etimología de una voz. De ellas interesa destacar la primera y la séptima -ambas están relacionadasporque en ellas se fija la corporación en la evolución que, con el paso del tiempo, experimentan el significado y -digámoslo con una terminología posterior- el significante de una palabra:

La primera regla que debe observar el Etimológico es atender a la significación de la Voz, y confrontarla con la significación de la voz matriz: porque si convienen las dos Voces, no hai mayor seña de la filiación que el común significado, aunque se diferencien en mucho

más sencillo cuando su etimología nos es conocida. No obstante, nuestros antepasados no impusieron nombres a todas las cosas considerando la naturaleza de estas, sino que en ocasiones obraron a su antojo, del mismo modo que nosotros, a veces, damos a nuestros siervos y posesiones un nombre según nos place» (Libro 1, «Acerca de la gramática», § 29, pp. 321-323, de la edición citada).

${ }_{16}$ Piénsese, por ejemplo, en la etimología practicada por Bartolomé Valverde en el Tratado de Etymologías de voces castellanas en estas Lenguas Latina, Hebrea, Griega, Árabe, de 1600, en la de Francisco del Rosal, en su Origen y Etimología de todos los vocablos originales de la Lengua castellana, de 1601, y en la de Sebastián de Covarrubias en el Tesoro de la Lengua castellana o española, de 1611.

Con estos antecedentes, la falta de aplicación de reglas lleva a G. Mayans a denunciar en sus Orígenes la práctica etimológica ejercida por Alejo Venegas: «Otros hay que, aunque saben varias lenguas y escriben sin pasión, ignoran o no practican las reglas que deben observarse para señalar los orígenes, y fácilmente se arrojan a decir lo primero que piensan. Entre los cuales cuento al eruditísimo maestro Alexio Venegas, el cual, al fin del docto libro que intituló Agonía del tránsito de la muerte, impreso en Alcalá, año 1565, dio algunas etimologías muy caprichosas, bien que otras muchas son felicísimas» (Orígenes, § 86, pp. 349-350).

17 La Academia denuncia esta situación con estas palabras: «esta definición [la de etimología] descubre por sí misma bastantemente la dificultad, y lo arduo de este estudio que pide mucha reflexión y gran peso: y supone al sugeto que lo cultiva mui adornado de erudición varia [...] El estudio es difícil, si bien mas que difícil es desgraciado» por causa de aquellos a los que «les parece estudio superfluo y vano la penetración de la propiedad, pureza y naturaleza de la Voz y su significación» (Discurso proemial, pp. XLVIII y XLIX). Y Sarmiento, como ya había hecho Mayans en el texto citado más arriba, defiende el método euclidiano empleado en su práctica etimológica: «No ignoro que casi riéndose dirán muchos: (... ¿Qué tienen que ver las demonstraciones de Euclides con las voluntariedades de los etimologistas? ¿Qué tiene que ver la evidencia matemática, con la falsa, dudosa o precaria probabilidad de una etimología? ¿Qué se puede esperar de un escrito, en el cual, seriamente, se propone persuadir que el juguete de etimologías se podrá reducir a demonstración?» (Elementos etimológicos, $\$ 169$, pp. 135-136).

${ }^{18}$ El contenido de las reglas es diverso; tratan distintos aspectos que pueden organizarse del siguiente modo: la primera, segunda y séptima reglas tratan de la alteración que puede experimentar la forma de una palabra con el paso del tiempo; la tercera regla lo hace sobre la conveniencia de leer los textos del pasado para documentar formas anteriores de la palabra; la cuarta, quinta, sexta y octava reglas tratan sobre la participación que tiene la morfología flexiva y derivativa en la investigación etimológica; la novena sobre el origen que muchas palabras tienen en una contingencia, que con el paso del tiempo puede llegar a olvidarse; y la décima trata del reconocimiento explícito de la arbitrariedad como factor de creación léxica (Vid. Discurso proemial, pp. LVI-LX). 
las letras: pues esta diversidad de letras puede ser variación por las causas que se dirán en la regla siete y la común significación es indubitable seña del origen: assi se ve en estas voces Obra, que viene de Opera, aunque solo convengan en la O, R y A: Hijo, que viene de Filius, y solo conviene en la I.

\section{$[\ldots]$}

La séptima regla, y más dilatada, es atender mucho a la variación de las letras, porque con el uso, y la mayor facilidad de pronunciar unas por otras, o con el deseo de suavizar las Voces, se han conmutado unas letras por otras, de donde se han desfigurado las Voces: y esto no solo al salir de la Lengua matriz, sino aun después de estar ya introducidas, y proprias las Voces en la Lengua Española: como se reconoce en la voz Hijo, que al salir de la Latina sin duda fue Fillo, y de allí a Hijo, y en la voz Desahuciar, que arriba queda explicada, y en la voz Conseillo, que se ha mudado en Consejo, y de otras muchísimas: como se reconoce, confrontando los libros antiguos con los modernos: y como esta mutación de letras, o substitución de unas en otras no es objeto, ni materia propria de la Gramática, y toca mui esencialmente a la Etymologia, es preciso expresarla con la mayor claridad, siguiendo en esto el exemplo del célebre Etymológico Menage, que con esta sola advertencia ilustró su libro y este fue el único proemial que juzgó necesario.

Lo que se desprende de la primera regla es que para fijar la etimología de una palabra la Academia concede tanta importancia al significado como al significante. La defensa de la etimología como la búsqueda del significado primitivo o verdadero y la exposición como primera regla del examen del significado, hacen de este un factor determinante para establecer el origen de una palabra: un elemento será el étimo de una voz si étimo y derivado están relacionados por el significado, además de por el significante, como se desprende de la variación de letras a que alude la regla séptima. El significante es importante, pero, para la Academia, no hay que «contentarse con el vago sonido de una voz», por lo que critica a aquellos a quienes «les parece estudio superfluo y vano la penetración de la propiedad, pureza y naturaleza de la Voz y su significación» ${ }^{19}$. Asegurada la coincidencia en el examen del significado hay que proceder con el del significante.

La idea es razonable porque pretende relacionar palabras que lo estén por su significado, y, a partir de ahí, examinar los cambios experimentados por el significante. Claro que este modo de proceder tiene el inconveniente de dejar de lado aquellos casos en que hay una conexión formal, pero no semántica, fruto de un cambio de significado. Con todo, la etimología científica posterior, y la aplicación de la ley fonética tienen en la forma de la palabra su centro de atención con el fin de identificar los cambios operados

${ }_{19}$ Prólogo, p. XLIX. Esta misma idea se desprende de la segunda regla que «es atender a la configuración de la voz, que bien examinada, no suele tener mas que una u otra letra común; pero en el todo de ella se halla tal relación con la matriz, que ninguno puede dudar de su filiación, siendo uno mismo el significado». Y a la importancia del significado en la determinación de la etimología se refiere también G. Mayans en la exposición de sus cánones etimológicos: «assí como la palabra originada tiene proporción con la original, las significaciones de una i otra la tengan también» (Orígenes, § 126, p. 384); y más adelante: «cuando se duda si un vocablo se ha de atribuir a una lengua o a otra, debe preferirse la lengua en la qual se expresa mejor la significación» (Orígenes, § 132, p. 386). 
entre la base y el derivado y no se atiende a una agrupación previa de acuerdo con el significado.

4. Con ese planteamiento etimológico dieciochesco, la forma de una palabra -que hay que analizar e, incluso, buscar en los testimonios más antiguos de la lengua para rastrear formas intermedias- puede haber experimentado cambios a lo largo del tiempo, «variación de las letras», como consecuencia de la facilidad y comodidad de la pronunciación. De acuerdo con las explicaciones propias de la época, en las que se confunde letra con sonido, o se identifica la una con el otro -se reconocen los cambios que se dan en el interior de una palabra, aunque no se determina la razón que los produce, más allá de la referencia, si se da, a las condiciones de la pronunciación-, la corporación académica explica los cambios de una palabra como resultado de una mutación; como parte de la regla séptima citada más arriba ofrece con todo detalle las siguientes transposiciones:

La $O$ se suele mudar en UE: como Corda Cuerda, Forum Fuero, Hospes Huésped, Mola Muela, Porta Puerta, Sporta Espuerta.

La $U$ en $O$ como Furca Horca, Gulosus Goloso, Ulmus Olmo, Stupa Estopa, Musca Mosca y las primeras Personas del plural en los Verbos.

La $A U$ se muda en $O$ : como Aurum Oro, Caulis Col, Maurus, Moro.

La $E$ se muda freqüentemente en IE: como Certus Cierto, Servus Siervo, Herba Hierba, Sinistra Siniestra, Terra Tierra, Fera Fiera.

La $I$ en E: como Infirmus Enfermo, Lignum Leño, Sicus Seco, Signum Seña.

La $B$ en $P$, pues según Quintiliano se confunden tanto en la pronunciación, que sin ofender el oído se pronuncia una por otra. Priges Latino, según él mismo, se dixo por mucho tiempo Briges; y assi los Españoles las mudamos muchas veces al respecto de su origen Latino: como Apricus Abrigo, Capra Cabra, Capillus Cabello, Caput Cabeza, Capere Caber, Opera Obra, Sapor Sabor.

La $B$ se muda en $D$ : como Cubitus Codo, Dubitare Dudar, Palpebrae Párpados.

A la $C$ y la $G$ las concede parentesco San Isidoro y se truecan con facilidad, tomando una por otra: como Dico Digo, Acutus Agudo, Amicus Amigo, Hac Hora Agora, Mica Miga.

$C L$ se muda en dos $l l$ con nuestra especial pronunciación, Clamare Llamar, Clavis Llave.

Quando en el Latin a la $C$ se sigue $T$, la $T$ se convierte en $H$, y tiene la pronunciación Cha, Cinctus Cincho, Dictus Dicho, Factus Hecho, Lectum Lecho, Lucta Lucha, Nocte Noche, Octo Ocho, Pectus Pecho.

La $D$ se consume o se pierde muchas veces, lo que los Latinos usaron en su propria Lengua, Cadere Caer, Fides Fe, Excludere Excluir, Audire Oir Radius Rayo.

La $F$ se ha mudado en $H$, o aspiración, sin más fin que la suavidad, Filius Hijo, Facere Hacer, Facienda Hacienda, Fervor Hervor.

La $G$ se muda en $I$ quando no se pronuncia $G$ : como Regnum Reino: y también se pierde muchas veces para suavizar la Voz: como Digitus Dedo, Frigus Frío, Sagita Saeta, Vagina Vaina.

La $L$ en J: como Allium Ajo, Articulus Artejo, Alienum Ajeno, Folium Hoja, Consilium Consejo.

La $L$ con la $R$ son convertibles: como Arbores Arboles, Cerebrum Celebro, Periculum Peligro.

La $N$ se añade, y se quita: como Insula Isla, Ruminare Rumiar, Salnitrum Salitre, Sponsus Esposo, Macula Mancha.

La pronunciación particular de las dos $n n$ por $\tilde{n}$ nace de dos $n n$ : como Annus Año, aunque también suele salir de otras letras: como de Aranea Araña, de Autummus Otoño, de Hispania 
España, de Dammnum Daño, de Vinea Viña: y como esta es pronunciación nacional propria, se ha acomodado, según que la Lengua se proporcionó a ella, o según la dificultad que encontraban los Españoles en la pronunciación Latina.

La $P$ se muda en $L$ muchas veces, quando en la Voz Latina a la $P$ se sigue $L$, para pronunciar Lla, lle, lli, llo, llu: como Plaga Llaga, Plantus Llanto, Planus Llano, Plenus Lleno, Ploro Lloro, Pluvia, Lluvia.

La $G$ y la $Q$ son tan parientas según San Isidoro, que las confunden los labios, y assi por Equus decimos Igual, por Aliquis Alguien, por Antiquus Antiguo, por Aqua Agua, por Aquila Aguila.

El mismo, y aun mayor parentesco logran la $T$, y la $D$, Catena Cadena, Factum Hecho, Latus Lado, Natare Nadar, Pietas Piedad, Vita Vida.

Debese empero advertir que estas mutaciones no suceden generalmente en todas las Voces, sino en algunas, porque en otras se conservan las matrices sin la menor variación.

Es mui usado, y mui introducido en la Lengua mudar letras, o añadir a las que havía la $L$, y la $R$, líquidas después de $B$, para suavizar la pronunciación de Admirabilis, Laudabilis, acabados en ilis, Admirable, Laudable, de Homo Home, y de aquí Hombre.

$\mathrm{Y}$ en otras varias ocasiones se hallan mudadas letras de las otras Voces, añadiendo, o quitando letras, de las quales no es posible dar más reglas que las dichas, porque no es general la mudanza, y se puede bastantemente conocer la Etymología, observando las reglas que hasta aquí se han escrito: como de Particeps Aparcero, esto es aparticero que quitado el $t i$ queda aparcero, mudada la terminación Aparejar de Parare, Acordar de Recordari, y otros muchissimos.

Esta explicación de los cambios que experimentan las letras de una palabra con el transcurso del tiempo se inscribe en una tradición que, en español, ya se encuentra en la obra de Aldrete, Del origen y principio de la lengua castellana ${ }^{20}$ : si la pretensión de este autor era demostrar que el castellano procede del latín por corrupción y no de otra lengua, la Academia -como también harán Mayans ${ }^{21}$ y Sarmiento ${ }^{22}$ en el siglo XVIII-

${ }^{20}$ Vid., por ejemplo, el libro II, capítulo IX, p. 197 de la edición citada en donde se explica ya que una de las causas de la variación del castellano con respecto al latín es que, en las palabras, «en muchas se han variado letras, o añadido o quitado».

${ }^{21}$ En la exposición de los orígenes de la lengua castellana trata de la etimología de las voces. Señala «unos como cánones o reglas generales de las letras que se suelen añadir, quitar o mudar en el principio, medio o fin de las dicciones al pasarlas de unas lenguas a otras, para que cuando se dude de su añadidura, quitamiento o mudanza de alguna o de muchas letras, se recurra a los cánones etimológicos, observando qué es lo que admite el genio de la lengua y qué no admite, qué sucede frecuentemente o raras veces, por qué la certeza de una etimología ayuda mucho para la averiguación de otras» (Orígenes, § 161, p. 398). Con respecto a la filiación del castellano con el latín señala también G. Mayans que «la lengua castellana fue romana en su origen» y advierte «a los que hubieren de sacar etimologías, que no solo las busquen en la lengua puramente latina, sino en la ya barbarizada, especialmente en los libros de la ínfima latinidad, en los glosarios de ellas, en los instrumentos más antiguos y en los primeros libros españoles, en cuyos escritos se ve de la manera que el latín se iba corrompiendo, o por mejor decir, se iba formando este nuevo lenguaje que hoy hablamos» (Orígenes, $\S 90$, pp. 353-354).

Con todo, el método no difiere del académico, pues la transposición de letras que experimentan las palabras le lleva a señalar, por ejemplo, que «A mudada en ue diftongo» convierte crassus en grueso. (Orígenes, $\S 161$, p. 400). A pesar de ello, el autor de las notas a la edición de los Orígenes, Eduardo de Mir, escribe, después de la exposición de las reglas: «Mayans, hombre tan juicioso como instruido, es indudablemente de los que menos han disparatado en el campo, casi siempre quimérico de las etimologías» (Orígenes, pp. 435-436).

${ }^{22}$ En el Onomástico etimológico de la lengua gallega explica Sarmiento la relación y evolución del latín al castellano del siguiente modo: «Sábese que la lengua de Italia, la francesa, la lemosina, castellana, portuguesa y gallega, no son más que dialectos de la latina; y que cada nación de las dichas no hizo más que torcer las 
lo que quiere es, ahondando en ese precedente, dar reglas para que pueda conocerse el origen latino del vocabulario castellano.

5. Esta explicación del cambio formal de una palabra como mera transformación o, como se dice en el discurso académico, «conmutación de letras», es criticada por el padre Sarmiento; para él la actividad etimológica es ajustable a reglas, resultado de los cambios en la pronunciación, y sostiene, después de defender el carácter riguroso y científico de la actividad etimológica ${ }^{23}$ nada más comenzar sus Apuntamientos para un discurso apologético sobre las etimologías, lo siguiente:

Pero como yo abundo en el sentido de que esa materia [la etimología] tiene fundamentos y reglas fundadas en la naturaleza de los órganos que concurren a la formación de la voz y loqüela; y que son más fijas y constantes que las de otras materias que usurpan el nombre de ciencias y artes; por eso no debe extrañar el lector que tomase la pluma (Elementos etimológicos, § 2, p. 289).

Con esta idea se entiende que, como enmienda a la totalidad de las reglas académicas, en el primer apartado de sus escritos publicados en el $B R A E$, titulado «Reparos a los prolegómenos», el sabio benedictino afirme que

las reglas de etimologías no son fundadas, aunque sean ciertas, pues debían fundarse en los órganos, semejantes o desemejantes, con que cada letra se pronuncia, como advierten los Griegos, Hebreos, Árabes, \& (Plana 60, cit. en p. 23).

Lo que supone dar un paso con respecto a la postura académica, que formulaba las reglas como un mero cambio de letras, y la mayansiana, que, como se ha señalado más arriba, ofrecía también unos cánones o reglas generales para la añadidura, mudanza o quitamiento de alguna letra, pues no se trata simplemente de describir la alteración gráfica una vez producida, sino de explicar esa alteración como resultado de la pronunciación de dos o más sonidos por un mismo órgano articulatorio; de explicarlo del modo como lo hace Sarmiento:

Dos cosas hay que considerar en las etimologías: $1 .^{\text {a }}$ las voces que significan ad placitum, estas no son de mi asunto, pero las debo suponer como ciertas e indisputables, 2. ${ }^{\text {a }}$ son las alteraciones y transformaciones, que padecen estas o las otras letras, cuando pasan de un labio a otro para pronunciarse. A estas alteraciones llama el vulgo corrupciones; y es un error craso. No es corrupción el que una nación no pueda pronunciar una letra y le sustituya otra del mismo órgano o del órgano inmediato (Elementos etimológicos, § 175, p. 137).

narices a las voces latinas con esta o con la otra inflexión, según el clima, el labio y los órganos de la loqüela. El que penetrare el sistema de estas inflexiones, con solo saber con extensión la lengua latina entenderá la mayor parte de las voces de todos los dialectos dichos» (\$90, p. 31). Además de dicha filiación, interesa destacar por la novedad con respecto a los otros autores la referencia a los órganos articulatorios como motores del cambio y de la evolución del latín al castellano.

${ }_{23}$ Al comienzo de los Apuntamientos defiende, como la Academia, la práctica etimológica del siguiente modo: «Es tan árida, estéril y desapacible la materia de etimologías, que no dudo extrañará al lector que yo hubiese querido gastar algún tiempo en escribir sobre esta materia. Poco estorbo sería que fuese árida y estéril, pues con el trabajo y cultivo se hará fértil, fecunda y veraz. El mayor estorbo consiste en el horrendo testimonio falso que se levantó a la materia de etimología, suponiendo que es materia sin fundamento ni reglas, totalmente voluntaria, ridícula y de puro capricho» (p. 289). 
Se podría sostener que esta idea subyace en la exposición académica, pues, aunque no se exprese explícitamente en el discurso académico, los cambios en las letras tienen su razón de ser en la pronunciación de esas letras, es decir, en los sonidos. Claro que en su contra están el hecho de que no se plantee con esta claridad -y si se comparte esta idea no habría motivo para no hacerlo-, y que la Academia no explique esos cambios como resultado de un proceso ordenado, producido porque dos sonidos sean articulados prácticamente de la misma forma, sino más bien como algo caprichoso o fruto de la corrupción, pues para la institución académica la evolución de una palabra tiene que ver más con «la mayor facilidad de pronunciar unas por otras o con el deseo de suavizar las voces», de la regla séptima, que con la aplicación de un criterio objetivo, científico, o por decirlo sencillamente, fonético.

6. La crítica de Sarmiento está dirigida a mostrar que la etimología científica -o mejor dicho, objetiva y rigurosa, pues más que científica es precientífica por la fecha en que se formula- se asienta en reglas que explican el cambio fonético, cambio de sonidos producidos por el mismo órgano articulatorio. El concepto de órgano cobra así importancia en los escritos del sabio benedictino y a él hace mención en varios pasajes de su obra ${ }^{24}$, ya que agrupa los sonidos atendiendo al que los emite. En el Teorema universalísimo, contenido en sus Elementos etimológicos (§ 193), clasifica los sonidos del siguiente modo de acuerdo con su articulación:

Vocales. A, E, I, O, U, Y

Labiales: B, P, Ph, M, U, V, F

Dentales: Z, S, Sc, Sch, Ts, R, X

Linguales: D, L, T, Th, N

Palatinas: G, L, C, K

Guturales $^{25}$

Y a continuación explica el significado de dicho Teorema:

Este teorema etimológico, con razón le llamo universalísimo, pues se podrá aplicar a todas las lenguas de todo el mundo, y con especialidad a las que tienen algún visible origen de otras. No puede haber origen sin que unas voces pasen a ser otras en el sonido, y no pueden pasar las voces si no hay alteración de las letras; y esa alteración de las letras no ha de ser a bulto, sino con algún sistema. Este solo se podrá formar atendiendo a la calidad de cada letra y al órgano con se pronuncia. Los órganos son 6, aunque si entran las guturales de los orientales, serán más (Elementos etimológicos, § 194, p. 142).

El etimólogo se fija en las alteraciones de una voz, en la forma, lo que puede explicar mediante reglas o «teoremas»: los teoremas los organiza en libros; el primero, «De las consonantes» (64 teoremas); el segundo, «De las vocales» (24 teoremas); el tercero es el «De las letras perdidas» ( 9 teoremas) y «De las vocales perdidas» (7 teoremas). El

${ }^{24}$ Aparece en los Elementos etimológicos, primero en la exposición de las primitivas lenguas naturales ( $\$$ 99 , p. 117) y después en la presentación del teorema universalísimo para las etimologías, que desarrolla más adelante: «El teorema universalísimo para las etimologías consiste en observar cuando la letra de un órgano de la voz, se muda en otra del mismo órgano. En este caso hay analogía. Al contrario, cuando la letra de un tal órgano se muda en otra letra de órgano diferente, no la hay» (\$ 105, p. 119). A partir de ahí se hacen frecuentes las referencias a la pronunciación de los sonidos y a los órganos que los producen.

25 Vid. los signos que reflejan las letras guturales en la introducción a los Elementos Etimológicos (p. 39). 
cuarto y último, «De las letras añadidas» (9 teoremas). En cada uno de ellos las reglas o teoremas se enuncian de acuerdo con la transposición de letras (Teorema 1: «B del latín $\mathrm{P} »$, como «Cast. Cabeza, de Capita»; teorema 8: «Ch de Pl», como «Cast. Ancho de Amplo», etc.). La exposición es similar a la de la Real Academia Española en su Discurso proemial sobre las etimologías y a la de Gregorio Mayans en sus Orígenes, pero no lo es el planteamiento previo que la justifica, si para ello ha de considerarse la participación de los órganos articulatorios en la pronunciación de los sonidos.

Con ello, este desarrollo de la indagación en la forma etimológica de una palabra es novedoso por su planteamiento y hace de Sarmiento un precursor, un adelantado para su tiempo, pues constituye la esencia de los actuales postulados etimológicos, y es el punto de partida de los cambios operados en la lingüística del siglo $\mathrm{XIX}^{26}$ de la mano de la fonética histórica. El método seguido es el siguiente:

Siempre que se me propone averiguar el origen de alguna voz o castellana o gallega, lo primero que hago es averiguar el actual y propio significado vulgar. Si la voz es pura gallega o antigua castellana, entro en la suposición que, por lo común, las más de esas voces tienen su origen en el latín, o en el puro, o en el de la Edad Media, o a primera vista o con algún rebozo que haya ocasionado la singular inflexión y analogía del patrio dialecto. Después advierto a qué clase de cosas pertenece el significado de la voz que se propone. Repaso mentalmente todas las voces latinas que sé, y son significativas de las cosas de aquella clase. Si entre ellas tropiezo con una que casi tenga las mismas letras y la misma coordinación que la voz propuesta, y que tiene el mismo significado, ya está hallado el origen, y nada más se necesita (Onomástico, vol. II, § 35-36, pp. 18-19).

Lo que explica con más claridad a través del siguiente ejemplo que le sirve para justificar la oportunidad de dicho método; en él trata de las consecuencias del cambio en el significado y la forma de la palabra:

La dificultad está en que las más de las voces han mudado de significación y se han desfigurado en sus letras. La solución de esta dificultad mejor se entenderá con ejemplos y se aclarará mejor la dificultad. Propónese v. g. la voz gallega «año» que significa el «corderito». Busco su origen en las voces latinas significativas de animales y tropiezo con la voz «agnus», que significa lo mismo. Pero si se propone la voz cordero no debo decir que se originó de la voz agnus, aunque «año» $\mathrm{y}$ «cordeiro» significan lo mismo. Las dos concuerdan en el significado, pero no en las letras. Así para hallar el verdadero origen de la voz cordeiro es preciso hallar una voz latina que concuerde en las letras y en el significado. De hecho hay esa voz y es de purísima latinidad Cordus, -a, -um (Onomástico, vol. II, § 38, p. 19).

La diferencia entre el método académico y el practicado por Sarmiento está en el énfasis que se pone en la semejanza formal entre la base y el derivado: la corporación académica se fija en el significado y en el significante, pero Sarmiento concede más importancia al significante que al significado en la determinación de la etimología de una voz (aunque no deje de lado lo semántico). Para nuestro autor la búsqueda de la etimología no termina al encontrar una voz en la lengua matriz con el mismo significado, ni es este factor determinante para su consideración, sino que, por el contrario, es definitiva

${ }^{26}$ Aunque todavía en el siglo XX, a propósito de la 17. edición del diccionario académico, afirma S. Gili Gaya (1947), en su reseña a la obra, que «la gran masa de etimologías responde a una época anterior a la constitución sistemática de la lingüística romance». 
la existencia de un étimo con «las mismas letras y la misma coordinación que la voz propuesta». Para el benedictino:

el arte de etimologizar es un arte de hacer análisis de una voz dada, y reducirla a su primitiva disposición cuando se formó. Si a esto se añade averiguar cual ha sido la primera significación y cuantas alteraciones ha tenido esta, no hay más que desear (Apuntamientos $\S$ 3, p. 289).

Que existe diferencia entre ambos planteamientos se comprueba al ver las críticas de fray Martín, pero también al observar que la Academia distingue, primero, entre etimología y correspondencia latina y, luego, en el curso de las primeras ediciones de su diccionario, termina por servirse de la una en lugar de la otra como si fueran intercambiables: la primera, la etimología, se asienta en la semejanza de significante (aunque pueda hacerlo también en el significado); la segunda, la correspondencia, solo en la de significado ${ }^{27}$. De hecho, algunas de las propuestas etimológicas del primer diccionario académico son criticadas por Sarmiento por parecer más una correspondencia -y algunas lo son- que una etimología.

7. Los aspectos del Diccionario de Autoridades sometidos a crítica por parte de Sarmiento son de diversa naturaleza. La mayoría de los comentarios se refieren a la etimología, pero también los hay de otro tipo: el significado, y el uso, es decir, la vitalidad y extensión geográfica y social de una palabra, son aspectos que también reciben la atención del sabio autor ${ }^{28}$.

La postura moderna que caracteriza el pensamiento etimológico de Sarmiento hace que se muestre partidario de dar la etimología, aun a riesgo de errar, antes que ofrecer la correspondencia latina, que no es otra cosa que una mera traducción de la voz castellana o del significado de esta al latín: si la correspondencia latina es una huella del pasado que liga el Diccionario de Autoridades con la lexicografía bilingüe y plurilingüe de los siglos XVI y XVII y sirve también para prestigiar el castellano por su relación con el latín ${ }^{29}$, la etimología abunda en esta idea de prestigio y, cultivada de manera diferente a como se había venido haciendo por autores como Covarrubias ${ }^{30}$, es uno de los rasgos que dota de modernidad a la obra.

Sin embargo, el diccionario da muy pocas etimologías en beneficio de la correspondencia latina; es decir, si ha de faltar alguna información, falta la etimología. Sarmiento

${ }^{27}$ Sarmiento participa también de la idea académica relativa a que, en palabras de filiación latina, solo interesa remontarse al latín para fijar una etimología, pues es el único modo de proceder con rigor en la búsqueda de la etimología de una palabra castellana (o gallega).

${ }^{28}$ Por ejemplo, de albanega, dice: «No es anticuada, que oy se usa en Toledo». Borde «es muy antiguo para venir del francés, y así es mejor del gótico». Farabustear y farabusteador son «voces de germanía, ladrón diligente; vendrá acaso del francés o ynglés Filibuster, pirata».

${ }^{29}$ La necesidad de acercar el castellano al latín, pero al latín clásico, hace que se prefiera la correspondencia latina a la etimología, pues no todas las voces castellanas proceden de la Edad de Oro de la lengua latina, sino que en muchos casos la base está en el latín vulgar o en el medieval barbarizado.

${ }^{30}$ La concepción etimológica de Covarrubias se asienta en los dos principios caracterizadores de esta actividad en el siglo XVII: en la consideración de la etimología como vía de conocimiento (la palabra es la cosa), y en la idea de que el origen del castellano es la lengua hebrea (Campos Souto 2006). 
critica las correspondencias latinas $-y$, por tanto, la falta de etimología- de las siguientes voces:

- Abarca: el Diccionario de Autoridades señala que la voz viene del verbo abarcar y que en latín es pero, onis 'media bota de cuero', lo que critica nuestro autor por ser una mera traducción y no el étimo del que procede. En su lugar propone la forma carbatina que, transmudando las letras, da abarcatina ${ }^{31}$.

- Abarcar: una observación similar hace de esta voz, de la que el diccionario dice que «puede venir de abrazar, trastocadas las letras». Da la correspondencia ulnis complecti. En cambio, Sarmiento señala que «si abarcar viene de abrazar, viniendo este de Brachium, será mejor latín Brachiis complecto que ulnis» (p. 24) ${ }^{32}$.

- Abate: en el sentido 'voz que advierte se aparte alguno de algún mal passo, u de otro peligro' la explica el diccionario con el recurso a la correspondencia latina cave, y Sarmiento apunta que «debe ser síncope de apartate, mudando la entenue en media; o de $a b i$, $t e{ }^{33}$.

- Abaxo: la correspondencia latina infra, deorsum, que da Autoridades, es corregida, de nuevo, por Sarmiento por la etimología latina bassus, o del griego bathos 'profundo', como abysus $^{34}$.

- Absorto: Autoridades da la correspondencia latina in stuporem versus. Stupore correptus; Sarmiento sencillamente dice que «viene de absorptus y así es mejor latín, que el circumloquio» ${ }^{35}$.

Este último ejemplo -se señalan aquí solo algunos para ilustrar la crítica- vuelve a poner de manifiesto que la presencia del latín en el diccionario se hace de dos maneras, con la etimología y con la correspondencia latina ${ }^{36}$. En otros casos -son la mayoría-Sarmiento critica sencillamente la etimología dada por Autoridades. Veámoslo a través de algunos ejemplos:

- Abella: Autoridades da el lat. apis, lo que Sarmiento corrige al explicar que procede de «apicula, como de speculum espello y espexo, mudada la $p$ en $b$ ». En cambio, en abeja el diccionario académico da correspondencia y etimología, apis, apicula, pero lo hace del siguiente modo: «Viene del Lat. Apis que vale esto mismo. Lat. Apis, Apicula» ${ }^{37}$.

- Acariciar: para Autoridades es voz compuesta de la partícula $a$ y del nombre caricia. Da la correspondencia latina. En cambio, Sarmiento propone la etimología charis, en griego, 'gracia o agrado' 38 .

- Arriscar: en Autoridades se explica que «pudo venir del verbo Arriesgar syncopado, mudada la $g$ en $c$ y suprimida la $e »$. A lo que replica Sarmiento que «no viene de Arriesgo,

${ }^{31}$ Hoy se sabe que abarca es voz de origen prerromano. Esa correspondencia latina se mantuvo hasta la 12. a edición, de 1884, momento en que la Academia volvió a registrar la etimología en el diccionario. Entonces le dio la siguiente: del b. lat. abarca.

${ }^{32}$ Ciertamente la propuesta va encaminada a sustituir la correspondencia latina por la etimología, que es *abbracchicare, de brachium 'brazo'. Así se recogió en la 12. a edición: del lat. ad, a, y brachicum, brazo.

${ }^{33}$ Cuando llegó el momento de consignar la etimología en la edición correspondiente del diccionario académico, la 12. a, se eliminó esta voz del diccionario.

${ }^{34}$ Con cambio de grafía, abajo no tiene etimología hasta la 15. a edición, de 1925 (de a y bajo).

35 Esta es la etimología que da la 12. a edición del diccionario.

${ }^{36}$ La traducción llega a esperpentos como el de claraboya: «Dice Oculis bovis; es latín ridículo; búsquese mejor origen, de clairvoyant». En la 12. ${ }^{a}$ edición, del fr. claire-voie.

${ }^{37}$ En la 12. ${ }^{a}$ edición abella no tiene etimología, y en abeja se explica: «del lat. apecula, d. de apes».

${ }^{38}$ La voz no tiene etimología en ninguna edición del diccionario. 
sino al revés; porque la $\mathrm{G}$ no se muda en $\mathrm{C}$, sino al contrario, y uno y otro de Risco, y este vendrá de resch».

- Corneja: Para Autoridades, «Lat. Cornix de donde viene», a lo que observa Sarmiento que «más se acerca a cornicula que cornix».

- Cuébano: «Algunos dicen haberse tomado del Latino Corbis, que significa esto. Lat. Cophinus, Corbis, is». Sarmiento precisa que «mejor de cophinus que de corbis».

Al lado de estas correcciones a la Academia, Sarmiento explica la etimología de una voz con el recurso al significado de las palabras que la componen (pero después de haber comprobado la relación formal que se establece entre ellas). Y lo hace por dos motivos:

a) porque Autoridades no lo hace, en voces como las siguientes:

- en acanthobola Autoridades dice que es el «instrumento con que los cirujanos sacan de la garganta las espinas que se clavan en ella, que es de la figura de un garabatillo mui sutil, cuya descripción trahe Esculteto en el Armamentario Chirúrgico, tabla 2, fig. 1. Es voz puramente griega. Lat. Acanthobola». Sarmiento es más explícito al decir que procede del griego acanthos 'espina' y de ballo 'arrojar' 39 .

- en acephalo Autoridades dice que es «voz griega, pero admitida y usada en Castellano y significa lo que no tiene cabeza: y assi la comunidad que no tiene superior se llama acephala, los concilios que se juntan sin autoridad legitima se llaman acephalos y los libros que no tienen principio también se reputan por acephalos. Lat. Acephalus». Sarmiento explica la formación de la palabra procedente del griego, de $A$ privativa y de cephalo 'cabeza' ${ }^{40}$;

b) porque Autoridades ofrece una explicación sirviéndose de la lengua castellana y Sarmiento va a más allá llegando hasta el significado en la lengua original, el latín:

- en a cercén Autoridades dice que «vale lo mismo que a raíz o por la raíz sin dexar nada de ella. Es compuesto de la partícula $A$ y de la palabra Cercén, que es syncope del verbo Cercenar. Regularmente se usa este adv. con el verbo Cortar y así se dice: cortar la cabeza a cercén, cortar la mano o el brazo a cercén. Lat. Penitus Prope raditus». Sarmiento dice que debe venir de circino, 'compás' ${ }^{41}$.

Hay, por último, entre sus propuestas etimologías idénticas a las de Autoridades; pero Sarmiento es más preciso, entonces, al explicar el proceso fonético, articulatorio, que lleva del latín al castellano:

- en ábrego tanto la Academia como Sarmiento dan como étimo el lat. africus, pero este autor explica que el cambio se produce «mudando la aspirada en media».

8. El conjunto de voces examinadas por Sarmiento es relativamente abundante ${ }^{42}$. No hay noticia en el texto de por qué se ocupa solo de estas palabras y no de otras, suscep-

39 Esta palabra solo se recoge en el Diccionario de Autoridades.

${ }^{40}$ En la 12. ${ }^{\text {a }}$ edición se explica así la etimología.

${ }^{41}$ A cercén, con primera documentación en el Diccionario de Autoridades, del lat. AD CIRCINUM 'en círculo', locución formada con el sustantivo CIRCINUS 'compás', del cual deriva el verbo CIRCINARE. En la 12. edición se da la etimología ofrecida por Sarmiento.

${ }^{42}$ En el apartado titulado «Reparos en los prolegómenos» señala voces de distintas letras. De la letra A, 90 palabras; de la B, 31; de la C, 114; de la D, 12; de la E, 35; de la F, 6; y de la G, 1. En otro apartado bajo el epígrafe «Voces castellanas cuya etimología se ha de buscar» señala, en la letra C, 20 voces, en la D, 8, en la E, 50, en la F, 41; en la G, 26 y en la H, 3. 
tibles de ser corregidas también en su etimología (hay en las reflexiones un apartado de «voces cuya etimología se ha de buscar» $\left.{ }^{\circledR}\right)$. Tampoco se conoce la fecha exacta en que Sarmiento redactó estas observaciones; la edición del texto no ofrece ningún dato. Lo único que se sabe es que han permanecido inéditas hasta la fecha en que la Academia las publicó en su boletín. Y queda pendiente también saber si la Academia conoció estas reflexiones, dada la presencia de Sarmiento en el Catálogo de Autoridades de la Academia, y si tuvieron algo que ver en la decisión de eliminar la etimología del diccionario a partir de entonces.

Pero lo importante, por lo expuesto en estas páginas, es que el sabio filólogo se detiene a examinar las etimologías que da la Academia y lo hace por dos razones: porque concede autoridad a la corporación académica y piensa que muchos pueden buscar en ella su enseñanza ${ }^{43}$, y porque es una manera de dar a conocer sus propios conocimientos. También porque estaba empezando a cambiar la consideración hacia la etimología: mientras la Academia está inmersa en una tradición que poco a poco irá acomodando a los nuevos tiempos, Sarmiento mira ya hacia el futuro. Y puede decirse que son los dos los polos de una situación de cambio que empieza a darse en el tratamiento de la etimología en el siglo XVIII: la Academia es el punto de partida y Sarmiento supone la consolidación de un modo de proceder que significa el inicio de la investigación científica del léxico, en general, y de la etimología, en particular.

\section{OBRAS CITADAS}

AldRETE, Bernardo (1993 [1606]). Del origen y principio de la lengua castellana. Edición de Lidio Nieto. Madrid, Visor.

Campos Souto, Mar (2006). «Sebastián de Covarrubias o la invención de la etimología», en El tapiz humanista: Actas del I Curso de Primavera, IV Centenario del Quijote, coordinado por Ana Eulalia Godoy Diz y Cristina Patiño Eirín, Santiago de Compostela, Publicacións Universidade de Santiago de Compostela, pp. 109-126.

Cotelo García, Rosalía (2010). La aportación lexicográfica de José Luis Pensado al Diccionario crítico etimológico castellano e hispánico de Joan Corominas y José Antonio Pascual, San Millán de la Cogolla, Cilengua.

Covarrubias, Sebastián (1984 [1611]). Tesoro de la lengua castellana o española. Con las anotaciones de R. Noydens. México, Turner.

Gili Gaya, Samuel (1947). «Reseña a Real Academia Española, Diccionario de la Lengua Española, 17. ${ }^{a}$ edición; Madrid, Espasa-Calpe, S. A., 1947, XXI + 1346 páginas», en Revista de Filología Española, XXXI, pp. 202-209.

Gutiérrez CuAdrado, Juan y Mónica Vidal Díez (2011). «Covarrubias en la encrucijada: la espesa selva del Tesoro», en Académica 6. Boletín de la Real Academia Conquense de Artes y Letras. Número extraordinario conmemorativo del IV Centenario de la publicación del Tesoro de la Lengua castellana o española de Sebastián de Covarrubias, pp. 419-458.

Isidoro de Sevilla (1983 [611]). Etimologías. Edición bilingüe de José Oroz Reta y Manuel A. Marcos Casquero. Introducción general por Manuel C. Díaz y Díaz. Madrid, BAC, 2 vols. 2. ${ }^{a}$ edición.

${ }_{43}$ Aunque el problema para que se cumpliera con este objetivo está en el hecho de que este escrito permaneció inédito. 
JiMÉNEZ Ríos, Enrique (2003). «El cultivo de la etimología en España durante el siglo XVIII», en Moenia, 9, pp. 253-274.

- (2008). «La actitud de la Real Academia Española para la inclusión de la etimología en el Diccionario», en Revista de Filología Española, LXXXVIII/2, pp. 297-324.

LÁzAro CARreter, Fernando (1985 [1949]). Las ideas lingüísticas en España durante el siglo XVIII. Barcelona, Crítica, 2. ${ }^{\mathrm{a}}$ edición.

Malkiel, Yakov (1996 [1993]). Etimología, Madrid, Cátedra.

Mayans, Gregorio (1873 [1737]). Orígenes de la lengua castellana. Reproducción de la edición facsímil editada en Madrid por Victoriano Suárez. (Reimpresión: Valencia, Librería ParísValencia, 1980).

Platón (1982). Cratilo o Del lenguaje. Traducción, notas e introducción de Vicente Bécares Botas, Salamanca, Ediciones Universidad de Salamanca.

Pensado, José Luis (1960). Fray Martín Sarmiento: sus ideas lingüísticas. Oviedo, Universidad de Oviedo, Cuadernos de la Cátedra Feijoo, núm. 8.

Real Academia Española (1984 [1726-1739]). Diccionario de Autoridades. Edición facsímil. Madrid, Espasa-Calpe.

- (1884): Diccionario de la lengua castellana. Duodécima edición. Madrid, Imprenta de D. Gregorio Hernando.

Rosal, Francisco (1992 [1601]). Diccionario etimológico. Edición facsímil y estudio de E. Gómez Aguado. Madrid, CSIC.

Sarmiento, Martín (1998 [1758-1766]). Elementos etimológicos según el método de Euclides. Edición y estudio por J. L. Pensado. A Coruña, Fundación Pedro Barrié de la Maza.

- (1998 [1770]). Discurso apologético por el arte de rastrear las más oportunas etimologías de las voces vulgares. (Editado en Elementos etimológicos según el método de Euclides. Edición y estudio por J. L. Pensado. A Coruña, Fundación Pedro Barrié de la Maza.

- (1999 [1757-1762]). Onomástico etimológico de la lengua gallega. Edición y estudio por J. L. Pensado. A Coruña, Fundación Pedro Barrié de la Maza.

- (1928a). «Escritos filológicos del padre Sarmiento. Reflexiones sobre el Diccionario de la Lengua Castellana que compuso la Real Academia Española en el año de 1726», en Boletín de la Real Academia Española, XV, pp. 22-38.

- (1928b). «Escritos filológicos del padre Sarmiento III. Elementos etimológicos según el método de Euclides», en Boletín de la Real Academia Española, XV, pp. 670-684.

- (1929). «Escritos filológicos del padre Sarmiento», en Boletín de la Real Academia Española, XVI, pp. 244-255, pp. 366-382.

- (1930). «Escritos filológicos del padre Sarmiento», en Boletín de la Real Academia Española, XVII, pp. 275-290, pp. 571-592, pp. 721-742.

- (1931). «Escritos filológicos del padre Sarmiento», en Boletín de la Real Academia Española, XVIII, pp. 118-135.

- (1970). Colección de voces y frases gallegas. Edición de J. L. Pensado. Salamanca, Ediciones Universidad de Salamanca.

ViñaZa, Conde de la (Cipriano Muñoz y Manzano) (1893). Biblioteca histórica de la filología castellana. Madrid, Imprenta y Fundición de Manuel Tello, 3 vols.

Zamboni, Antonio (1988). La etimología. Traducción de Pilar García Mouton. Madrid, Gredos. 